\title{
Magic beans
}

\section{The Japanese invader that's good for you.}

\section{Vaclav Smil}

n July 1853, Commodore Matthew Perry's small flotilla cast its anchors off Uraga at the entrance to Edo (Tokyo) Bay. Its mission was to end Japan's quarter of a millennium of isolation under the Tokugawa shogunate. The black ships returned the next spring, when Perry signed the treaty. The shogunate was persuaded not just by the ships' large guns but also by the demonstrations of American technical superiority that included the telegraph and a miniature steam locomotive.

Mission accomplished, Perry returned bearing samples of Japanese products. As well as the predictable silks, lacquer boxes and exquisite porcelain, these included white and red soy beans. Several months later the US Patent Office was offering the seeds to American farmers, but there were few takers. Three decades later, Lewis Sturtevant noted in his exhaustive survey of edible plants that soy beans had begun to appear as a novelty item in US seed catalogues.

In China their cultivation is ancient: nearly 5,000 years ago the legendary Emperor Shennong made soy beans the only legume of his five life-sustaining grains, and millennia of culinary evolution have produced an enormous range of soy-based foodstuffs throughout East and Southeast Asia. Immature pods are eaten as a vegetable. Mature seeds are sprouted or milled to make flour. Protein in milled soy beans can be precipitated by coagulants, usually calcium and magnesium sulphate, to make bean curd Japanese tofu and Chinese dòfu. Seeds are ground or boiled and then fermented to prepare soy sauces and pastes such as Japanese miso and natto and Indonesian tempeh. And the seeds, which are nearly $20 \%$ lipids, make an excellent cooking oil consisting of $85 \%$ unsaturated fatty acids. Modern processing has also added an array of flavoured drinks to traditional soy bean milk.

The West was slow to adopt soy beans: in the 1920s American farmers still devoted more land to sweet potatoes. Soy beans finally took off in the 1930s, but it was the prosperity following the Second World War, with its rising demand for cheaper meat, that made them a major crop. Corn has only $10 \%$ protein, but most soy bean cultivars have about $36 \%$, nearly twice as much as other legumes. Mixtures of corn, a high-yielding source of carbohydrates, and highly proteinaceous (44\%) soy bean meal, produced by first extracting oil with organic solvents, have come to dominate feeding formulas around the world. American cattle, German broilers, Japanese pigs - and Chinese carp - all yield more meat thanks to Glycine max.

The US soy bean harvest passed 10 million tonnes (Mt) in the early 1950s. It is now 70-75 Mt a year - almost half of the global total. Soy beans are the country's second most valuable crop, close behind corn and worth nearly three times as much as wheat, and grow on more than $15 \%$ of all arable land. Brazilian production, geared to exports, has grown even faster. The area planted with soy beans has expanded more than 60 -fold since the late 1950s; Brazil now produces about $30 \mathrm{Mt}$. Argentina harvests about half as much as this, relegating the Chinese harvest to fourth place. The Japanese now grow a mere 3\% of what they consume. Boiled tofu served in the temple precincts of Kyoto's Higashiyama or tofu-based nouvelle cuisine in Tokyo's Ginza now come from seeds harvested, and often organically grown, in Iowa or North Carolina.

The symbiotic relationship between soy beans and the Rhizobium bacteria in nodules

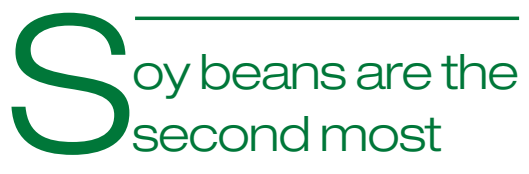
valuable US crop, and grow on more than 15\% of all arable land.

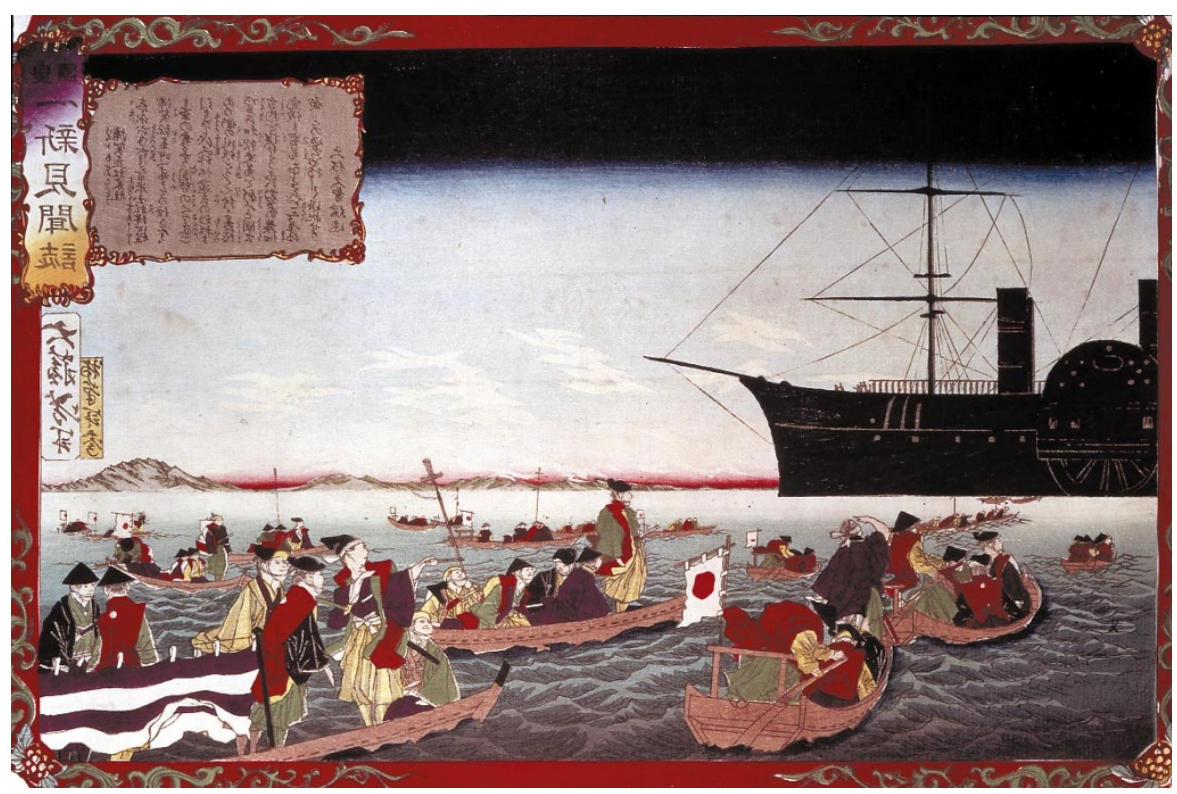

Soy ahoy: the beans reached the West via Perry's 'black ships', shown here arriving off Tokyo in 1853. attached to the plant's roots can provide as much as $100 \mathrm{~kg}$ of nitrogen per hectare per year. So it may come as a surprise to learn that at least a fifth of the US crop now regularly receives nitrogen fertilizers. This is because a higher proportion of the biomass of modern cultivars is in the seed, which is removed from the field. So, even with minimal losses to leaching or erosion, more nitrogen is extracted than is fixed by bacteria. In contrast, Brazilian soy beans receive no extra nitrogen. Perhaps the most important environmental downside of soybeans' rise is that, as with all other crops grown in rows, their cultivation can lead to higher soil erosion.

The world's diet is unthinkable without soy beans, but they remain a fringe foodstuff in the West. Only soy sauce has become a universal condiment - bean curd, although readily available, is still a culinary oddity. A change would serve women particularly well. Soy bean foods contain very high concentrations of isoflavones, particularly genistein. These phytoestrogens can alleviate the symptoms of menopause, and their consumption has been linked to reduced risks of breast cancer in East Asia. Soy proteins also lower levels of blood cholesterol, and some, although not all, epidemiological studies link their intake with a reduced risk of cardiovascular diseases. Greater enthusiasm for the subtle taste of tofu could thus have highly cost-effective health benefits.

Vaclav Smil is at the University of Manitoba, Winnipeg, Manitoba R3T 2N2, Canada. 